\title{
Manichaean Women in a Pseudo-Augustinian Testimony: An Analysis of the North African Testimonium de Manichaeis sectatoribus
}

\author{
Johannes van Oort ${ }^{*}$ \\ University of Pretoria \\ j.van.oort@planet.nl
}

\begin{abstract}
The article analyses the rather unknown and understudied Testimonium de Manichaeis sectatoribus. This Pseudo-Augustinian text has come down to us in two Latin manuscripts (one from Saint Gervais, Paris; the other from a Vatican codex), and interestingly elucidates the place and role of women among the Manichaeans of Roman Africa. Differences between the MSS lead to the conclusion that, in all likelihood, the text underwent some 'masculinisation' in the course of its tradition. In its (in all probability) most original form, i.e., in the MS from Saint Gervais, Manichaean women appear to have played a major role. On the basis of the Testimonium, furthermore, it may be suggested that —at least in Roman Africa-female Manichaeans were (re)named with names that were highly symbolic to the 'Religion of Light'.
\end{abstract}

\section{Keywords}

Testimonium de Manichaeis sectatoribus - women - Manichaeism - Augustine of Hippo - persecution Early Christianity - Roman North Africa - religious (re)naming

In a previous study on 'Manichaean Women in Augustine's Life and Works', I I described how, at different stages of his life, Augustine came in contact with female Manichaeans and valued their significance very differently. In that article, I successively discussed the place and role of the mother of the bishop to whom Monnica once (ca. 375 AD) communicated her sorrows about her son; ${ }^{2}$ the place and role of Augustine's long-time (ca. 373-385) 'concubine' who in all probability was, like her companion, a Manichaean during that time; ${ }^{3}$ the place and role of Cypriana, the wife of the Manichaean auditor Romanianus who, like her husband, seems to have been a Manichaean for a long time as well (from ca. 375 onwards); ${ }^{4}$ the place and role of a certain Eusebia, a Manichaean electa, and of the young girl Margarita, in all likelihood also a (future) electa, ${ }^{5}$ both of whom were denounced before an ecclesiastical tribunal in Carthage in the year $421 .{ }^{6}$ At the end of the article it was

\footnotetext{
* I would like to acknowledge Jason BeDuhn and Madeleine Scopello for their attentive reading as well as Yolande Steenkamp both for her reading and other assistance. This article was completed with the help of the National Research Foundation (NRF) in South Africa.

1 J. van Oort, 'Manichaean Women in Augustine's Life and Works', Vigiliae Christianae 69 (2015) 312-326.

2 See Augustine’s Confessions 3, 21.

3 Main sources: Augustine's Confessions 4, 2 and 6, 25.

${ }^{4}$ Main source: Augustine's Epistula 259.

${ }^{5}$ Or, more exactly, an oblate entrusted to electae in order to be prepared for her own status as electa.

${ }^{6}$ Main sources: Augustine's De haeresibus 46 and Possidius, Vita Augustini 16. For the question of whether or not the charge of committing a eucharistic rite with human 'semen' (i.e., male sperma and female menstrual fluid) was justified, see my recent articles in Vigiliae Christianae: "Human Semen Eucharist” Among the Manichaeans? The Testimony of
} 
concluded that, on the one hand, the presence of Manichaean women in Augustine's life and works was considerable, but that, on the other hand, future studies on the place and role of women (either in the position of electae, auditrices or - in some way or another-associated with Manichaean men) would likely add to our picture of Manichaean women in Augustine's time and world.

Of course it may be possible that, through new discoveries, new texts will become available that may further elucidate the presently rather dim picture. Unfortunately, genuine Manichaean texts from Roman Africa are still very rare: apart from a number of literary texts transmitted by opponents of Manichaeism such as Augustine and his pupil Evodius, ${ }^{7}$ the only actual example is still the Codex Thevestinus or (perhaps better) Fragmenta Tabestina, which were discovered near Algerian Tébessa in 1918. ${ }^{8}$ One may ask whether a study of the original manuscript, presently kept in the Bibliothèque Nationale in Paris, may reveal a female scribe or a related female activity. ${ }^{9}$ The same goes for the question whether Manichaean women played their part in the composition and performance of church music. ${ }^{10}$ Also, one may rightly ask whether their role in the dissemination of Manichaean belief and practices was perhaps as pivotal in Roman Africa as already suggested by the unknown Christian bishop (possibly Theonas) from Egyptian Alexandria. He, indeed, stated in a pastoral letter from the late third century: ' ... we may be on our guard against those who with deceitful and lying words steal into our houses [cf. 1 Tim 5:13; 2 Tim 3:6?], and particularly against those women whom they call "elect" and whom they hold in honour ....'11

A document which, for the moment, may serve to further elucidate the place and role of women among the Manichaeans of Roman Africa, is the rather unknown and understudied

Testimonium de Manichaeis sectatoribus. As far as I can see, this Testimony has been neither included in any anthology of Manichaean texts, nor extensively discussed in one of the leading books providing comprehensive overviews of Manichaeism and its history. Nevertheless, the Testimony mentions a considerable number of Manichaean women: a certain Maria; a certain Lampadia; a certain Caesaria; a certain Lucilla; perhaps a certain Candida; a certain Victorina and/or (Victorina) Hispana; and an unnamed 'sister of Paul'. In the manuscript tradition the text goes under the name of Augustine, but in actual fact both its author and time of origin are unknown. Below I will discuss what is in my view the most plausible conjecture in this regard.

First, however, more information is in order on this testimonium, which is curious for a number of reasons. The French abbé Jacques-Paul Migne, who is well known as editor and publisher

Augustine Reconsidered in Context' and 'Another Case of Human Semen Eucharist Among the Manichaeans? Notes on the "Ceremony of the Fig" in Cyril of Jerusalem's Catechesis VI'.

${ }^{7}$ E.g. Augustine's c. ep. fund.; c. Faust.; c. Fel.; nat. b.; Evodius, de fide.

${ }^{8}$ Cf. e.g. F. Decret, 'Aspects de l’Église manichéenne. Remarques sur le Manuscrit de Tébessa', in A. Zumkeller (ed.), Signum Pietatis, Würzburg 1989, 123-151 (repr. in Decret, Essais sur l'Église manichéenne en Afrique du Nord et à Rome au temps de saint Augustin. Recueil d'études, Roma 1995, 27-53); J.D. Beduhn \& G. Harrison, 'The Tebessa Codex: A Manichaean Treatise on Biblical Exegesis and Church Order', in: P.A. Mirecki \& J.D. BeDuhn (eds.), Emerging from Darkness. Studies in the Recovery of Manichaean Sources, Leiden etc. 1997, 33-87; M. Stein, Manichaica Latina, vol. 3,1: Codex Thevestinus. Text, Übersetzung, Erläuterungen, Paderborn 2004 and idem, Manichaica Latina, vol. 3,2: Codex Thevestinus. Photographien, Paderborn 2006.

${ }^{9}$ While the leading recent book by Kim Haines-Eitzen, The Gendered Palimpsest. Women, Writing, and Representation in Early Christianity, Oxford 2013, does not deal with Manichaean women, it may provide clues for further study.

${ }_{10}$ Perhaps a clue may be found in Augustine's Confessions 10, 49-50 and mor. 2, 46.

${ }^{11}$ See C.H. Roberts (ed. \& transl.), 'Epistle against the Manichees', in: Catalogue of the Greek and Latin Papyri in the John Rylands Library, Manchester 3, Manchester 1938, 39. Greek text conveniently also in A. Adam, Texte zum Manichäismus, Berlin 19692, 53 and Roberts' translation also in Iain Gardner \& S.N.C. Lieu, Manichaean Texts from the Roman Empire, Cambridge 2004, 115. Text and translation (based on C.H. Roberts) again in Greek and Latin Sources on Manichaean Cosmogony and Ethics. Translated by Greg Fox and John Sheldon. Compiled with introduction and commentary by Samuel N.C. Lieu (CFM, Subs. VI), Turnhout 2010, 36-37. 
of, for instance, the Patrologia Latina, states that it was first published by the famous ecclesiastical historian Cesare Baronius (1538-1607), who is said to have taken the text from a manuscript from Saint Gervais in Paris (where it was an appendix to Augustine's De haeresibus) and printed it as an appendix to the fifth (sic) volume of his Annales Ecclesiastici. ${ }^{12}$ This text edition by Baronius has been reprinted by Migne in volume 42 of his Patrologia Latina as an admonitio preceding the text of Augustine's Contra Felicem Manichaeum. ${ }^{13}$ Another edition of the same testimonium - but this time based on a Vatican codex - was provided by the also famed editor of rare manuscripts, Angelo Mai, in his Nova Patrum Bibliotheca. ${ }^{14}$ This edition was reprinted by Adalbert Hamman in his Patrologiae Latinae Supplementum $2 .^{15}$

I present here the text from the Vatican MS as printed by Mai, ${ }^{16}$ followed by a translation and variae lectiones based on the MS of Saint Gervais ${ }^{17}$ as printed in the sixth volume of Baronius' Annales ${ }^{18}$ and in MPL 42. In both manuscripts the text is preceded by the abjuration of Mani by a certain Cresconius $^{19}$ about whom no further particulars are known: ${ }^{20}$

Ego Cresconius unus ex Manichaeis scripsi, quia si discessero ante quam gesta subscribantur, sic sim habendus, ac si Manichaeum non anathemaverim. Felix conversus ex Manichaeis dixi sub testificatione Dei, me omnia vera confiteri, de quo scio, esse Manichaeos* in partes caesarienses Mariam et Lampadiam uxorem Mercurii argentarii; cum quibus etiam apud** electum Eucharistum pariter oravimus; Caesariam et Lucillam filiam suam; Candidum*** qui\# commoratur Thipasa,\#\# Victorinum, \#* Hispanam,\#* Simplicianum Antonini patrem, Paulum et sororem suam qui sunt Hippone, quos\#** etiam per Mariam et Lampadiam scivi esse Manichaeos.\#*** Hoc tantum scio. Quod si aliud inventum fuerit me scire supra quam dixi, me reum ego ipse confiteor.

\footnotetext{
${ }^{12}$ Cf. J.-P. Migne in MPL 42, 517-518: ‘... professio a Felice quodam ... quam in Appendice tomi quinti Annalium edidit Baronius, descriptam ex Gervasiani Parisiensis collegii codice, in quo post librum de Haeresibus ad Quodvultdeum haec legunter ...'. The first edition of volume 5 appeared in 1594, but neither in this publication nor in a number of subsequent editions of this fifth volume could I find the text. I did find the text, however, printed (but not as an appendix) in the sixth volume of Baronius' Annales, both in the edition published in Luca in 1740 (p. 474-475) and in the edition published by Augustinus Theiner, Bar-le-Duc 1866, 431.

${ }^{13}$ MPL 42, 517-518. I used the original edition published in Paris in 1841.

${ }^{14}$ A. Mai, Nova Patrum Bibliotheca, I, Roma 1852, 383. The first sentence of his introduction to the text (ibid., 382-383) runs: 'In codice vaticano, olim Reginae Suecorum DLXIX. (qui ex antiquioribus sumptus fuit Gallicanis codicibus) p. 18, post anathematismum, quo concluditur liber secundus actorum sancti Augustini cum Felice manichaeo, sequitur alius anathematismus, sine dubio Augustini, qui videtur ineditus ...' (382).

${ }^{15}$ PLS 2, Paris 1960, 1389.

${ }^{16}$ Hamman follows his source closely.

${ }_{17}$ Unfortunately, my personal enquiries in the Bibliothèque Nationale in Paris in June and July 2014 did not yield a positive result. The final conclusion seems to be that the MS Gervais is no longer there. I thank Madeleine Scopello for her kind help.

18 There are no differences between the two editions that I was able to consult.

${ }^{19}$ Curiously only indicated as 'C.' by Baronius.

${ }^{20}$ Cf. e.g. A. Mandouze et allii, Prosopographie Chrétienne du Bas-Empire, 1, Afrique (303-533) [henceforth PAC], Paris 1982, 250 s.v. Cresconivs 44. The ingenious attempt of Judith and Samuel Lieu ("Felix conversus ex Manichaeis": A case of mistaken identity', JTS 32, 1981, 173-176) to identify this Cresconius as being felix (felix thus considered to be an adjective and not a noun c.q. personal name) should be dismissed for a number of reasons. See e.g. F. Decret, 'Du bon usage du mensonge et du parjure', in: idem, Essais [n. 8], 118-119 n. 21; G. Sfameni Gasparro, 'The Disputation with Felix: Themes and Modalities of Augustine's Polemic', in: J.A. van den Berg a.o. (eds.), 'In Search of Truth': Augustine, Manichaeism and Other Gnosticism. Studies for Johannes van Oort at Sixty, Leiden-Boston 2011, 521-522. (Even if this Cresconius were the same as this Felix-quod non-, this would cause no essential change in the subject matter of our following argument.)
} 
* B. Manichaeos vel Manichaeas M. Manichaeos vel Manichaeas

** M. apud omit.

*** B. Candidam M. Candidam

\# B. quae M quae

\#\# B. Thipasae M. Thipasae

\#* B. Victorinam Hispanam M. Victorinam Hispanam

\#** B. quas M. quas

\#*** B. Manichaeas M. Manichaeas

In translation:

I, Cresconius, a member of the Manichaeans, have written this, because if I depart before the public records are signed, I will still be held to be a Manichaean, as if I had not abjured Mani. I, Felix, converted from the Manichaeans, have said with God as my witness, that I have confessed the whole truth about what I know: Manichaeans in the region of Caesarea are Maria and Lampadia, the wife of Mercurius the money-changer (together with them, we also prayed at the home of the Elect Eucharistus); Caesaria and Lucilla, her daughter; Candidus who lives at Tipasa; Victorinus; Hispana; Simplicianus, the father of Antoninus; Paul and his sister who come from Hippo and whom I know as Manichaeans through Maria and Lampadia. This is all I know. If it is subsequently found out that I know more than I have declared, I confess that I myself shall be held liable.

Apart from a minor divergence such as the (faulty) omission of apud by Migne, ${ }^{21}$ the two text traditions have some striking differences. All but one of these differences ${ }^{22}$ pertain exactly to the role of women in Manichaeism. The Vatican manuscript in the version of Mai-which has become some sort of standard version ${ }^{23}$ - speaks of a certain Candidus and a certain Victorinus, whereas the Paris manuscript — which seems to be more original ${ }^{24}$ - in the version of both Baronius and Migne speaks of the female Manichaeans Candida and Victorina from Spain, and also in the beginning and near the end articulates that it deals with both Manichaei and Manichaeae.

How may these differences be explained? In all likelihood the text underwent some 'masculinisation' in the course of its tradition. During this process words such as 'vel Manichaeas' may have been left out and 'quae' became 'qui'. Also, because Mai supposed he read 'Victorinus' and could identify this person as the man who, acting as a subdeacon in the Catholic church of Malliana in Mauretania Caesariensis, was deposed as a Manichaean, an affair that Augustine wrote about in his letter $236 .^{25}$

\footnotetext{
${ }^{21}$ Prayer in Manichaeism is not directed to an Elect; the correct text tells that members of a Manichaean cell prayed apud, i.e., 'at the home' of a certain Elect Eucharistus or-perhaps better in view of the itinerant state of the Manichaean Elect- ' 'at the place' where Eucharistus was present.

22 Thipasa or Thipasae, the latter version (as a locativus) seems to be preferred.

${ }^{23}$ See, apart from the reproduction in Hamman's authoritative PLS, e.g. Mandouze's PAC (n. 20), s.v. 'Caesaria' etc., and, most recently, B.D. Shaw, Sacred Violence: African Christians and Sectarian Hatred in the Age of Augustine, Cambridge 2011, 340-341.

${ }^{24}$ Cf. the quote from Mai above, n. 14: ‘... qui ex antiquioribus sumptus fuit Gallicanis codicibus ...'.

${ }^{25}$ Mai, Bibliotheca, I, 383 n. 1: 'Prorsus de hoc Victorino manichaeo tota est epistola Augustini CCXXXVI'.
} 
In actual fact, however, the situation is even more complex. François Decret, who dealt with the testimonium several times - although in a deficient and contradictory manner ${ }^{26}$ - in a rather recent article supplied an image of the text from the Vatican manuscript. ${ }^{27}$ From a close reading of this reproduction ${ }^{28} \mathrm{I}$ conclude that it, in fact, runs as follows (of course, italics and square bracket are mine):

Felix conuersus ex Manichaeis dixi sub testificatione

Dei me omnia uera confiteri, de quo scio; esse Manichaeos

uel Manichaeas in partes Caesarienses Mariam et Lampadi-

am uxorem Mercurii argentarii; cum quibus etiam apud Electum

Eucharistum pariter orauimus, Caesariam et Lucillam filiam

suam, Candidum qui commoratur Thipasa, Victorinam, Hispanam,

Simplicianum Antonini patrem, Paulum et sororem suam

qui sunt Hippone, quas etiam per Mariam et Lampa-

diam sciui esse Manichaeas. Hoc tantum scio: quod si aliud

inuentum fuerit me scire supra quam[,] dixi, me reum

ego ipse confiteor.

According to this version, the Vatican text comes very close to the Paris text as transmitted by Baronius and Migne, and even mentions one extra woman in line 6, namely Hispana (instead of Victorina Hispana). Perhaps inspection of the original MSS may corroborate beyond doubt that —as reported to be the case in the Paris MS-it should also read quas and Manichaeas in all but the last full sentence as well.

What can we say about the women involved? According to this Felix-who surely should not be identified with his namesake who in the year 404 disputed with Augustine in Hippo, ${ }^{29}$ and about whom we do not know anything more than what is supplied in this testimonium —all women come from the partes Caesarienses, i.e., the region of Caesarea (present-day Cherchel in Algeria).

First we come across Maria and Lampadia, the wife of a certain banker named Mercurius. Both Maria and Lampadia turn out to be simple auditrices, firstly because both-together with Felixprayed 'at the home' (apud) of the Elect Eucharistus (in all likelihood all three persons belonged to the same cell around this electus) and, secondly, in the case of Lampadia also because she is married to a certain banker, Mercurius. From the name Mercury we may possibly infer that, like her husband, the auditrix Lampadia came from a pagan background. Both ladies seem to have spoken about other Manichaeans to Felix, for near the end of the text it is said that, 'through Maria and Lampadia', he got knowledge of a certain Paul and his sister 'who come from Hippo'.

The second pair of women consists of Caesaria and her daughter Lucilla. In the case of the mother Caesaria, we can be sure she was an auditrix. In the case of Lucilla, one could perhaps suppose that she was a girl similar to the Carthaginian Margarita mentioned in Augustine's De

\footnotetext{
${ }^{26}$ Cf. F. Decret, Aspects du manichéisme dans l'Afrique romaine, Paris 1970, 333-335; idem, Mani et la tradition manichéenne, Paris 1974, 155; idem, L'Afrique manichéenne, I, Paris 1978, e.g. 193-195; idem, 'Du bon usage du mensonge' in: Essais, 118-119.

${ }^{27}$ F. Decret, 'Des manichéens en Maurétanie Césarienne au VI siècle. L'exemple de Caesarea et Tipasa: un billet de délation', in: Vbique amici. Mélanges offerts à Jean-Marie Lassère, Montpellier 2001, 345.

${ }^{28}$ Until now I could neither get hold of a new image of the MS nor inspect the original in the Vatican Library in Rome. I thank Madeleine Scopello for her supporting letters from Paris to Rome in May-June 2014, and my son Hans-Willem van Oort for his subsequent enquiries in situ.

${ }^{29}$ So, rightly, Decret on several occasions; cf. most recently Sfameni Gasparro, 'The Disputation with Felix' (n. 20), 521522.

30 'Hippone' is 'from Hippo' and not 'at Hippo' as, for instance, stated in the relevant articles ('Maria 2' etc.) in PAC.
} 
baeresibus 46, 9, i.e., a young woman destined to become an electa. ${ }^{31}$ The fact that she is explicitly mentioned together with her mother (and not with some Elect), however, seems to argue against such a supposition. It seems best, then, to consider her as an auditrix as well. The case of Caesaria and Lucilla, like the example of Paul and his sister, indicates that Manichaeism was spread within family relations.

According to the Vatican text, Candida is no longer a candidate for our list because this manuscript reads Candidus, as is also indicated by the pronomen relativum qui. Perhaps one might suppose this to be the correct reading, maybe also because this person is said to live at Tipasa (i.e., nearly $24 \mathrm{~km}$ from Caesarea, the capital of the Roman province of Mauretania). As a rule, men in those times had a better chance than women to become known by travelling, or otherwise. Perhaps, however, a close look at the MSS may still bring to light a certain Candida. All the same, the name of Candidus or Candida ('shining white'), though also known in Catholic and Donatist circles, ${ }^{32}$ seems to fit a Manichaean well. If the name was a newly applied surname, one may conclude that we are dealing with an Elect, whether female or masculine.

Whereas Baronius and, in his wake, Migne read 'Victorinam Hispanam' as one name ('Victorina from Spain'; 'the Spanish [lady] Victorina'), the Vatican MS according to Mai (and Hamman) reads: 'Victorinum, Hispanam'. However, the reproduction from the Vatican codex in Decret's article clearly reads 'Victorinam, Hispanam', ${ }^{33}$ thus revealing two ladies: Victorina and Hispana. Because no other particulars are revealed about them, we are in all likelihood dealing with two female auditors from the region of Caesarea. ${ }^{34}$

The last mentioned female person is the sister of a certain Paul. Like her Manichaean brother, the soror Pauli was originally from Hippo. ${ }^{35}$ Felix knows them to be Manichaeans through Maria and Lampadia. Since no further particulars are mentioned, we are in all probability again dealing with 'Hearers'. As in the case of the mother Caesaria and daughter Lampadia, Manichaeism was spread within a family.

As noted above, the Felix of our testimonium is by no means identical with the Manichaean doctor Felix whom we know from Augustine's c. Felicem. Can we be sure, however, that the testimony comes from Augustine's age and world? The relevant lemmata in $P A C$ are all introduced by the phrase 'une époque impossible à préciser', and subscribed by the rather indefinite indication ' $\mathrm{IV}^{\mathrm{e}} / \mathrm{VI}^{\mathrm{e}}$ s.'. Indeed, it might be possible that the text dates from Vandal or even Byzantine times. It seems much more reasonable, however, to suppose that it dates from Augustine's age. In both the Paris and the Vatican MSS our testimonium is closely associated with texts from Hippo's bishop. Besides, the procedure of denunciation by Felix closely fits the one prescribed by Augustine to Deuterius of Caesarea in his ep. 236: the ex-Manichaean (and ex-Catholic cleric) Victorinus of Malliana, if he wishes to be received in order to do penance, may only be believed after having denounced all Manichaeans, both in his city and in the whole province of Caesarea Mauretaniae. ${ }^{36}$ We also encounter this procedure in the background of Augustine's ep. 222 to Quodvultdeus with

\footnotetext{
${ }^{31}$ Cf. Decret, L'Afrique manichéenne, I, 370.

32 Apart from this Manichaean Candidus, PAC (185-186) lists three Catholic bishops and one Donatist presbyter.

33 Although Decret (p. 344) himself translates this as 'Victorinus, Hispana'.

${ }^{34}$ Both with regard to Victorinus 24 and Hispana, $P A C$ remarks: 'Felix ....qui le/la nomme parmi ceux des quatre qui habitent Hippo ..... In my view, there is no reason to read the text as stating that four of the denounced Manichaeans live at Hippo: it is only said that the two last mentioned (Paul and his sister) come from Hippo.

${ }^{35}$ I.e., in all likelihood, Hippo Regius, at a distance of some $814 \mathrm{~km}$ from Caesarea (Cherchel). Apart from the writings of A. (and Possidius' vita), this is then another indication of Hippo being an important centre of Manichaeism.

${ }^{36} \mathrm{E}$ p 236, 3: 'Petenti autem paenitentiae locum tunc credatur, si et alios, quos illic nouit esse, manifestauerit uobis non solum Mallianae sed in ipsa omnino prouincia'.
} 
regard to a certain ex-Manichaean Theodosius. ${ }^{37}$ Moreover, it fits well with the modus operandi prescribed in the (virtually contemporary) Theodosian laws. ${ }^{38}$

As discussed above, the apparent changes in the text Testimonium de Manichaeis sectatoribus appear to indicate a later downplay of the presence and, thus, conceivably, of the importance of Manichaean women. In its (in all likelihood) most original form, i.e., in the MS from Saint Gervais, Manichaean women played a major role, however. Future research may perhaps corroborate the impression that - either after becoming a Manichaean in their adult years, or already as a child descending from 'Hearers' - the female Manichaeans ${ }^{39}$ were (re)named with names highly symbolic to the 'Religion of Light', such as Lampadia, Lucilla, and Candida. ${ }^{40}$

\footnotetext{
${ }^{37}$ Ep. 222, 3: 'Peto etiam mihi rescribere non graueris, quem ad modum sit in fide catholica ille Theodosius, per quem Manichaei nonnulli sunt proditi, et ipsi, quos ab eo proditos putamus esse correctos'.

${ }^{38}$ Codex Theodosianus: Les lois religieuses des Empereurs romains de Constantin à Théodose II (312-438). Volume I: Code Théodosien Livre XVI (SC 497), Paris 2005, e.g. Cod. Theod. XVI,5,9 of the year 382 which with regard to the heresy of the Manichaeans is speaking of inquisitores, a tribunal, persons who indicate and denunciate, etc. Laws against the Manichaeans were adapted and repeated several times (see e.g. Cod. Theod. XVI,5,38 [of the year 405]; 5,40 [year 407]; 5,41 [407]; 5,43 [408]). Cf. e.g. Codex Theod. XVI,11,1 (399) for the jurisdiction of a bishop in religious matters. Latin texts, French translations and elucidations also in E. Magnou-Nortier et alii, Le Code Théodosien, Livre XVI et sa réception au Moyen Âge, Paris 2002.

${ }^{39}$ Like, perhaps, their masculine counterparts. Cf. e.g. Eucharistus both in the Paris and the Vatican MSS. PAC does not list any other Eucharistus (or Eucharista, for that matter).

${ }^{40}$ Candida, if the Vatican MS provides the right reading.
} 